\title{
Ou-Testamentiese teologie en Skrifbeskouing
}

\section{PM VENTER}

Die sola scriptura-beginsel by Luther is ook 'n opdrag aan die Bybelwetenskap van hierdie eeu.

\section{DIE BELANG VAN DIE HERMENEUTIESE "VORVERSTÄNDNIS"}

Tydens hulle teologiese opleiding, maak predikante kennis met bepaalde hermeneutiese benaderings tot die Ou Testament, sowel as bepaalde eksegetiese tegnieke wat daaruit voortvloei. Teen die tyd dat hulle in die predikantspraktyk staan, het hulle hierdie hermeneutiese beginsels hulle eie gemaak en beskik hulle oor 'n redelike vaardigheid in die hantering van die eksegetiese tegnieke. Met verloop van tyd is dit egter hierdie tegniekvaardigheid wat eerste in die slag bly. Die predikant verloor sy bedrewenheid, veral as hy nie volhou met grondige studie nie. Die hermeneutiese beginsels wat hy aangeleer het, bly hom egter veel langer by. In sy voorbereiding vir preke en Bybelse voordragte, val hy telkens intuitief terug op die bepaalde benadering tot die $\mathrm{Ou}$ Testament waarin hy geskool is. Daarom is dit belangrik om nie net te praat oor nuwere eksegetiese metodes nie, maar ook aandag te gee aan die huidige gedagtegang van die Ou-Testamentiese teologie.

\section{DIE VERHOUDING OU TESTAMENT - NUWE TESTAMENT}

2.1 Een van die belangrikste vraagstukke waarmee die predikant worstel, is wat hy met die Ou Testament moet maak. Moet hy dit ignoreer en liefs nie daaruit preek nie? Of moet hy ter wille van die gewete tog wel daaruit preek? Moet hy dit gebruik as 'n negatiewe teenbeeld van die verlossing in Christus? Of moet hy dit positief gebruik as 'n boek van voorbeelde hoe gelowiges moet lewe? Die meeste van hierdie oplossings is al in die verlede beproef. Die oplossings is altyd in een van drie rigtings gesoek: of die Ou Testament is buite rekening gelaat, ò die Ou Testament is as die kern beskou waaraan die Nuwe Testament slegs ' $n$ aanhangsel is; ò die Nuwe Testament is as die kern beskou en die Ou Testament is in terme daarvan verstaan. Aan die basis van hierdie klassifikasies, sien ons elke keer die simplistiese gedagte dat die Ou Testament en Nuwe Testament elkeen met 'n enkele term beskryf kan word. Na gelang die kernwoorde van die twee Testamente versoenbaar is, al dan nie, word bepaal wat die verhouding is. 


\subsection{Die degradering van die Ou Testament}

Tydens die Reformasie is daar weinig onderskeid gemaak tussen $\mathrm{Ou}$ en Nuwe Testament. Die ortodokse kerkleer is geformuleer en "dicta probantia" is as bewysstukke uit enige van die Testamente getrek. (Vgl Nineham, hoofstuk 2, 1976.) Dit was tydens die opkoms van die historisme dat $\mathrm{Ou}$ en Nuwe Testament al verder van mekaar verwyder is en al skerper teenoor mekaar gestel is. 'n Hele nuwe konsep van geskiedenis word ontwikkel. Daardie "objektiven treibenden Kräfte der Geschichte" (Krauss, 1970, p 348) word gesoek wat by elke fase van geskiedenis gemoeid is. Die kragte wat in die moderne geskiedenis aan die werk is, word gesien as kragte wat alreeds veel verder ontwikkel het as die kragte wat in die verlede die geskiedenis beheer het. Agter die Ou Testament sit daar'n veel ouer geskiedenis as die Nuwe Testament, wat deur veel minder ontwikkelde kragte gedryf is. Die Ou Testament verteenwoordig daarom ook 'n veel ouer en meer primitiewe vorm van die godsdiens, wat verder van die hede verwyder staan as die Nuwe-Testamentiese godsdiens. Die Ou Testament moet vanuit sy oorspronklike tyd dus verstaan en ook geëvalueer word as 'n voor-Christelike dokument, wat los en verwyderd staan van die Nuwe Testament en die Christendom. In hierdie gees beskou Adolf von Harnack in 1924 die voortgesette gebruik van die Ou Testament as "die Folge einer religiös-kirchlichen Lähmung" (Kosak, 1968, p 216). Vir Bultmann is daar geen teologiese kontinuiteit tussen Ou en Nuwe Testament nie. Die Ou Testament is vir hom "Geschichte des Scheiterns und Versagens" (Kosak, 1968, p 217). Waar die Ou en Nuwe Testament op historiese gronde skerp onderskei word en die verlede negatief geëvalueer word as dit wat geen belang vir die hede het nie, word die Ou Testament uitgeskakel en die Nuwe Testament onkrities en onhistories as ' $n$ abstrakte verlossingsleer gebruik.

\subsection{Die Ou Testament as Christelike boek}

Die geskrifte van Barth en die dialektiese teologie het 'n belangrike rol gespeel in die hernieude aandag wat die Ou Testament sedert die dertigerjare ontvang het. Die inkarnasie van die Woord bied die analogie vir die Skrifwording van die openbaring. Menslike woorde in al hulle gestaltes, selfs van 'n vergange Ou-Testamentiese godsdiens, is diensbaar aan die selfopenbaring van God. Alle dele van die Bybel dra 'n getuiekarakter: die Ou Testament 'n vóór-Christus getuienis en die Nuwe Testament 'n ná-Christus getuienis. In 1934 verskyn op hierdie spoor die werk van W Vischer, "Das Christuszeugnis des Alten Testaments". Vischer wil nie net, soos sy tydgenoot Fr Baumgärtel die Ou Testament vanuit die Nuwe Testament lees as 'n "Grundverheissung" wat alleen vanuit Christus verstaan- 
baar is nie, maar hy wil elke teks in die Ou Testament allegories op Christus betrek. Soos met alle allegorie, word die uitgangspunt hier verabsoluteer ten koste van die unieke aard en karakter van die $\mathrm{Ou}$ Testament. By Vischer word die Ou Testament eintlik verswelg in die allegorie, sodat dit geen eie boodskap meer dra nie en die vraag na ' $n$ verhouding tussen $\mathrm{Ou}$ en Nuwe Testament eintlik verlore gaan. Veel meer genuanseerd is die bekende werk van Th $C$ Vriezen van 1949, "Hoofdlijnen der Theologie van het Oude Testament". OuTestamentiese teologie is vir Vriezen Christelike teologie. Soos Eissfeldt wil hy nie die Ou Testament godsdienshistories benader nie, maar vanuit die Christelike teologie. Die Ou Testament is soos die Nuwe Testament openbaringslektuur waaruit die konfessie moet sistematiseer. Op eg Lutherse wyse word geloof en kennis hier skerp onderskei en word daar nie veel ruimte gelaat vir'n ondersoek na die historiese aspek van die Ou Testament nie. Waar die Ou Testament nie in dialektiese samehang met die Nuwe Testament gelees word nie, maar eintlik daarin opgaan, word die historiese karakter en die eiesoortige getuienis van die Ou Testament in der waarheid tot swye gebring.

\subsection{Die Ou Testament as geskrif in eie reg}

Dit was veral aan die oplewing in die godsdiensgeskiedenis te danke dat die Ou Testament as geskrif in eie reg gesien is. Die godsdiens van Israel word toenemend as godsdiens met sy eie karaktertrekke en eienskappe gesien, wat godsdienstig en histories in noue samehang met die Christendom bestudeer moet word. By Van Ruler word die Ou Testament aanvanklik oorbeklemtoon as die eintlike Bybel waarby die Nuwe Testament slegs as addendum gelees moet word. By Von Rad word die ewewig herstel en die OuTestamentiese teologie word in ' $n$ nuwe rigting gestuur. Die Ou Testament word nie langer as geskrif van 'n oerreligie beoordeel en verstaan nie, maar as die resultate van die godsdienstradisie. Dit is die uitkoms van die oorgelewerde belydenisse van Israel waarin hulle vertolking van God se optrede met hulle weergegee is. Dit is belangrik om op die verskuiwing in klem te let. Vanaf Vriezen se openbaringsbeskouing verskuif die klem na die ontvangers van die openbaring en hulle historiese vormgewing aan hierdie historiese openbaring. Veral die rol van Israel as godsdiensgemeenskap en die korporatiewe denke wat agter die versameling en oorlewering van die tradisie sit, geniet die aandag. Dit hou minstens twee belangrike implikasies in. Enersyds word die aandag gevestig op die historiese en pluriforme karakter van die Ou-Testamentiese materiaal. Dit is 
nie moontlik om al die materiaal van die Ou Testament langer onder 'n enkele begrip te sistematiseer nie.

Tweedens moet die eie aard van die Ou-Testamentiese materiaal baie noukeuriger beskou word. Dit is die geformuleerde geloofsbelydenis van 'n godsdiensgroep. Die vorms waarin die materiaal van die Ou Testament gesmee is, is die van 'n credo, 'n belydenis van God. Daarin vind Von Rad dan 'n ooreenkoms tussen Nuwe-Testamentiese Christusgetuienis en Ou-Testamentiese Godsbelydenis. Om die ooreenkoms in getuieniskarakter, maar tog verskille in geskiedenis aan te dui tussen die Testamente, maak Von Rad gebruik van die metode van tipologie. Soos die tradisie aangegroei het, het Israel sy belydenis telkens geskoei op die lees van die bestaande formulerings. Daardeur is die aard van Israel se toekomsverwagtings tot op groot hoogte geantisipeer. Met die koms van Jesus Christus gebeur iets wat presies volgens die verwagting is, dit vervul, maar dit tegelyk oortref en radikaal vernuwe. Om hierdie korrespondensie tussen nuwe en ou gebeure, maar tegelyk totale vernuwing uit te druk, word in die Nuwe Testament van die stylfiguur van tipe en antitipe, ofte wel tipologie gebruik gemaak. Alhoewel Von Rad hier 'n legitieme argument het wat met groot sukses op baie tekste toegepas kan word om die resiproke verhouding van die Testamente te verklaar, moet daar 'n voorbehoud vir die vrye gebruik van hierdie metode gestel word. Dit mag nie verhef word tot die enkele teologiese grondplan waarop die eenheid van die Testamente gebou is nie (Hasel 1972, p 113). Omdat tipologie ook met geskiedenis te doen het, waarsku Gunneweg (1978, pp 209-217) teen die gebruik van ' $n$ tipologie wat deur ' $n$ moderne begrip van geskiedenis oorwoeker is. Die moderne begrip van geskiedenis, soos reeds deur Kraus aangedui, soek na die dryfvere agter die gebeure en stel gebeure in ' $n$ oorsaaklike en gevolglike verband tot mekaar. Die tipologiese binding van gebeure in die Bybel werk glad nie met hierdie moderne beginsel om een saak as die aanleidende dryfveer tot die ander te sien nie. Van albei gebeure word wel aangeneem dat hulle historiese gebeure is, wat beskryfbaar is in terme van plek en omstandighede. Hulle word egter tipologies verbind omdat hulle van dieselfde tipe is, daar ' $n$ ooreenstemming in die aard van die gebeure is wat daar plaasgevind het. In die Ou-Testamentiese gebeure is daar ooreenstemming met die van die Nuwe Testament, omdat dit dieselfde God is wat by albei betrokke is en die aard van sy optrede dieselfde is. Tipologie het dus te doen met die ooreenkoms in die aard van die verskillende gebeure. Ook die gedagte van vervulling, moet in hierdie lig gesien word. Die gebeure wat in die Ou Testament beskryf word, vertoon bepaalde kenmerke. Die gebeure wat in die Nuwe Testament beskryf word, toon presies hierdie selfde kenmerke, beweeg in presies deiselfde bane, maar beweeg 
een stap verder as die punt waar die ou gebeure opgehou het. In daardie sin maak dit die gebeure van die Ou Testament vol, vervul dit wat alreeds geskep is.

Waar Von Rad met die vorming en tradisie van Bybelse materiaal gewerk het, werk Bevard S Childs met die finale versameling van hierdie geskrifte tot ' $n$ Bybelse kanon. Childs is van mening dat die godsdienswetenskaplike benadering wat met 'n oervorm en -geskiedenis gewerk het, die tradisiegeskiedenis wat met oorlewering en versameling gewerk het en die Bybelse Teologie met die betekenis van die Ou Testament vir die vergange tyd, almal een belangrike konteks buite rekening gelaat het, naamlik dié van die kanon. Die mankement by Von Rad was dat hy nie aandag gegee het aan die "canonical forces at work in die formation of the traditions into a collection of scripture during the post-exilic period" (Childs, 1979, p 699) nie. Die vraag moet gevra word na die konteks van die godsdiensgemeenskap waarin die Bybel as kanon aanvaar is en waarin dit steeds as kanon funksioneer: "These Scriptures must be interpreted in relation to their function within the community of faith that treasured them" (Childs, 1970, p 99). Dit gaan hierby nie soseer om die geskiedenis en motivering van kanonwording nie, maar om die vraag hoe die Bybel as afgehandelde kanon binne die geloofsgemeenskap gehanteer en verstaan is. Vir Childs het hierdie kanon as 'n geheel gefunksioneer, nie as afsonderlike passasies nie. Elke passasie is binne die geheel van die kanon gesien en geïnterpreteer. Daar is 'n dialektiese verhouding tussen elke deel en die res van die Bybel en ' $n$ dialektiese relasie tussen die twee Testamente. Die eksegese moet nie die twee Testamente probeer harmonieer of eenstemmige leerstukke uit albei Testamente probeer opstel nie, maar moet uit die dialektiese verband van die twee Testamente alles uithaal wat oor dieselfde God en sy reddingswerke gesê word. Die huidige ondersoeker is histories ewe ver verwyderd van $\mathrm{Ou}$ en Nuwe Testament en is afhanklik van die volle omvang van albei saam in hulle dialektiese verband om vir hom die kanon van sy huidige lewensomstandighede te wees. In hierdie oproep om elke passasie binne die geheel-konteks van die Bybelse kanon te lees, is Childs in ooreenstemming met die strewe van Hans-Joachin Kraus om eksegese te bedryf "im Horizont Kontext-offenen Forschens und im Aufsuchen biblisch-theologischer Perspektiven" (1970, p 371). In sy voorgestelde metode om te begin by $\mathrm{Ou}$ Testamentiese passasies, wat ook in die Nuwe Testament aangehaal word, slaan Childs egter die bal ver mis. Hy verskraal sy teologie tot slegs die dele van die $\mathrm{Ou}$ Testament wat ook in die Nuwe Testament aangehaal word. Sy strewe om die gehele kanon as konteks te berde te bring, gaan daarmee heeltemal verlore. ' $n$ Verdere beswaar is dat hy totaal afwyk van Kraus se program om van klein tot groot te werk en eers met 
buurperikope, dan hoofstukke, dan Bybelboeke, ensovoorts te werk. Childs negeer in sy voorbeeld voorafgaande of opeenvolgende perikope en vergelyk Ou- en Nuwe-Testamentiese perikope sommer direk met mekaar. Dit bring noodwendig 'n verlies van teologiese inhoud mee.

Gerhard Hasel som die huidige stand van sake op as 'n toenemende gewaarwording "that the Testaments witness to multiple interrelationships" (1972, p 124). Die verhouding kan nie met 'n enkele begrip of eenvoudige sleutel uitgedruk word nie, maar behels verskillende fasette. Histories gesien, was daar met die koms van Jesus alreeds ' $n$ baie ou tradisie (wat ons as die Ou Testament ken) wat as matriks vir sy heilswerk gedien het en waarby $\mathrm{Hy}$ aangesluit het en die tradisie verder gevoer het. Barr praat van ' $n$ inkarnasie in die bepaalde Joodse konteks van die eerste eeu, 'n "mental matrix for the incarnation" (1966, p 158). Jesus neem dan bepaalde elemente uit hierdie bestaande tradisie oor en voer dit verder, soos dit neerslag gevind het by die apostels en die Nuwe Testament. Hierdie dialektiek tussen bestaande tradisie en die heilswerk van Jesus, vorm die verbindingslyn tussen $\mathrm{Ou}$ en Nuwe Testament. Om hierdie verhouding uit te werk, vra volgens Hasel 'n "multiplex approach". "No single category, concept, or scheme can be expected to exhaust the varieties of interrelationships" (1972, p 125).

Tussen Ou en Nuwe Testament is daar dus kontinuïteit en diskontinuilteit. Daar is ooreenkomste, maar ook skerp verskille. Ons kan nie met enige simplistiese formule werk nie. Op 'n eie wyse vanuit eie tyd en omstandighede getuig verskillende dele van die Ou Testament van die God van wie die Nuwe Testament uit die mond van verskillende getuies getuig dat $\mathrm{Hy}$ in Christus Jesus na ons toe gekom het.

\section{OPENBARING IN DIE GESKIEDENIS}

As daar tussen die Testamente geen eenvoudige verbintenis is nie, dan is dit logies om te vra of daar dan nie ten minste in die Ou Testament een deurlopende lyn is waaruit alles verklaar kan word nie. Dit het teen die middel van hierdie eeu 'n algemene gesegde geword om te sê dat God homself in die geskiedenis geopenbaar het. Vir baie is dit ook die hermeneutiese sleutel waardeur die Ou Testament verstaan kan word. Die Ou Testament is 'n boek van heilsgeskiedenis. Die kritiese vraag is natuurlik of dit deurgaans in die $\mathrm{Ou}$ Testament om "heil" gaan? Profeteer die profete nie meer van onheil wat dreig as van heil nie? Sedert die werk van B Albrektson, "History and the gods", in 1967 verskyn het, waarin aangetoon is dat ander volke ook historiese gebeure in herinnering geroep het, waarin hulle hulle gode se wense leer ken het, was dit ook nie langer 
houdbaar om te sê dat die God van Israel uniek is om homself in historiese gebeurtenisse aan sy volk bekend te maak nie. 'n Vraag wat nog skerper is, is die vraag na wat ons presies bedoel as ons sê dat God in die geskiedenis opgetree het, met sy mense gepraat het, en so meer? Langdon B Gilkey (1961, p 194-205) het aangetoon dat sowel liberale teoloë, wat nie van die supranaturalistiese wil weet nie, as nieu-ortodoksie en Bybelse teologie-aanhangers, wat 'n letterlike uitleg voorstaan, onlosmaaklik deel is van die moderne denksisteem van kausaliteit en universaliteit. Albei kategorieë sit in die verleentheid dat hulle nie kan verklaar wat daar byvoorbeeld gebeur het by die Riet See, of by die stilstand van die son by Josua nie, en so meer. Die rede daarvoor is te vinde in die oortuiging dat ons nie dink dat die Israeliete in 'n ander werklikheid van oorsaak en gevolg en tyd en ruimte geleef het, as waarin ons self ook maar leef nie. As iets by ons nie letterlik sus of so kan gebeur nie, kon dit in daardie tyd ook nie gebeur het nie. Daarom kan dit gebeur dat ons Bybelse terme gebruik van God wat optree, praat, doen, en so meer, maar iets totaal anders daarmee bedoel as wat die Bybelskrywers self bedoel het. Dennis Nineham (1976) het van 'n hele "kulturele rewolusie" gepraat wat plaasgevind het sedert die tyd van die Bybel tot nou toe. Alle denke is so ge-enkapsuleerd in sy eie tyd en kultuur, dat 'n mens kwalik uitdrukkings vanuit een tyd net so kan oorneem in 'n ander tyd, sonder dat daar 'n groot verskuiwing in betekenis ontstaan. Daarom is dit onhoudbaar om die hele Ou Testament as geskiedenis te beskryf waarin God "optree" en "praat", terwyl ons nie in eietydse taal kan verduidelik presies wat ons daarmee bedoel nie.

Die probleem het veral duidelik geword in die historisme van die vorige eeu. Die historiese kritiek het soveel teenstrydighede, anachronismes en onverklaarbaarhede in terme van die moderne geskiedskrywing in die Pentateug gevind, dat hulle dit as nodig beskou het om 'n "korrekte" geskiedenis van Israel te rekonstrueer. Die geskiedskrywing van Israel, aangevuur deur die argeologiese fondse, het tot 'n selfstandige dissipline ontwikkel. Gerhard Hasel (1972, p 62) onderskei tans twee histories-kritiese denkskole elk met sy eie rekonstruksie van die proto-geskiedenis van Israel: Die AltNoth-groep en die Albright-Wright-Bright-groep. Stuhlmacher het tereg daarop gewys dat die historiese kritiek altyd gekoppel staan aan ' $n$ bepaalde filosofie van geskiedenis (1979, p 65). Die eindresultaat word steeds bepaal deur een of ander rasionele, of idealistiese of eksistensialistiese of materialistiese beginsel. By Franz Hesse (1960) word die histories-kritiese rekonstruksie van Israel se geskiedenis teenoor en bo die Bybelse weergawe van die geskiedenis gestel. Hesse wil nie sy geloof op die Israelitiese weergawe van wat gebeur het, bou nie, maar op die getroue weergawe van wat daar werklik 
gebeur het. In hierdie beskrywing is die verlossingsgeskiedenis van God ingesluit, sodat hierdie geskiedenis in kontemporêre taal die probleem van misverstand van Bybelse begrippe uitskakel en die basis vir vandag se geloof in God is. Hempel aanvaar dat die historiese kritiek nie in staat is om die geskiedenis van Israel te rekonstrueer nie. Die Bybelse weergawe van daardie geskiedenis kan ook maar menslik onbetroubaar wees. Dit gaan vir hom nie soseer om die hóé alles gebeur het nie, maar om die dát van God se optrede in die geskiedenis. Fohrer sien 'n essensiële eenheid tussen feit en interpretasie, gebeure en verslag. Hy wil dus nie die moderne rekonstruksie afspeel teen die klassieke beskrywing van die Bybel nie. Nog 'n verdere poging om die Bybelse beskrywing met 'n moderne stelsel te vervang, kom van Pannenberg. Hy werk met 'n begrip van universele geskiedenis waarin alle realiteite een groot totaliteit vorm. Bybelse geskiedenis en eietydse geskiedenis, soos by Moltmann, is gelykelik betrokke in een groot wêreldgeskiedenis wat deur die belofte-woord voortgestu word.

Teenoor die historiese kritiek se, wat Von Rad noem, "krities vasgestelde minimum", stel hy die kerugmatiese beeld van die "teologiese maksimum" (1969, p 120). Dit is nie 'n rekonstruksie van Israel se geskiedenis wat vir ons die teologiese perspektief sal gee nie, maar ' $n$ oorvertelling van die geskiedenis soos Israel self dit gesien en beleef het. Daarmee bring Von Rad 'n koerswysiging aan, wat tot vandag toe staan: nie 'n moderne beeld van die geskiedenis of die oorspronklike gebeure nie, maar die reaksie van Israel op die gebeure, hulle ervaring van die gebeure en die oorgelewerde vertellings word voortaan die voorwerp van ondersoek. Die klem verskuif na Israel se siening van gebeure en Israel se oorvertelling van historiese gebeure in 'n eiesoortige geskiedenisaanbieding. Hoewel Von Rad self in sy "Theologie des Alten Testaments" die histories-kritiese beeld van die geskiedenis bloot vervang met 'n geskiedenis van die tradisie van Israel, het hy die weg geopen vir'n studie van Israel se godsdiens in sy eietydse idioom. Dit gaan nie verder oor die onbeskryfbare dade van God in die geskiedenis nie, maar om die besondere reaksie wat God op 'n unieke wyse by Israel teweeggebring het en in hulle belydenis neerslag laat vind het as norm vir alle komende geslagte (Gilkey, 1961, p 201).

James Barr erken geredelik dat daar in die Bybel ' $n$ "Heilsgeschichte" is, 'n "reeks van gebeure op die vlak van menslike lewe en in historiese volgorde, waardeur God homself geopenbaar het" (1963, p 201). Hy dink egter nie dat dit die enigste deurlopende tema in die Bybel is nie. Die beskrywing van hierdie gebeure is egter vir Barr geen geskiedenis in die moderne sin van die woord nie. Die mededelinge van die skepping, die vloed, die eksodus is almal verhale van gebeure waarin God opgetree het ( $p$ 198). Die oomblik 
egter, as ons hulle as geskiedenisse beskryf, gebruik ons 'n buiteBybelse beskrywing wat nie die werklike aard van hierdie literatuur beskryf nie. Claus Westermann onderskei tussen die twee sake met die begrippe "Geschehen" en "Geschichte" (1978, p 5). Gunneweg laat volledig ruimte vir die historiese aspek. In die Bybelse materiaal gaan dit om die "historisiteit van menslike bestaan" (1978, p 216). Die Ou Testament vertel van historiese gebeure en daar kan selfs 'n lyn van Adam af getrek word tot na die tyd van die ballingskap. Hierdie lyn het egter geen inherente waarde of betekenis nie. "Teologiese betekenis kan nie gevind word in die geskiedenis waarvan die Ou Testament die buitelyne skets, veel minder in die "werklike geskiedenis", insluitende die geskiedenis van die tradisie wat deur Bybelse kritiek gerekonstrueer word nie; maar eerder, soos wat historiese verandering voorkom en horisonne aanskuif, is die belangrikste saak die voortdurende poging van Israel in hede en verlede om homself te probeer verstaan in terme van Jahwe se belange" (Gunneweg, 1978, p 205). Dit gaan dus nie hier om die aaneenskakeling van gebeure in oorsaaklike en gevolglike verband nie. Die gedagte is eerder om gebeure aan mekaar te ryg of oor mekaar te skuif as gebeure wat vanuit verskillende hoeke bevestig dat God daar is en Israel steeds sy volk is. Dit is eerder ' $n$ identifikasie van historiese gebeure met mekaar. Die huidige gebeure word oor die vorige gebeure geskuif en word so 'n paradigma vir toekomstige gebeure. Vreemd vir die moderne geskiedskrywing, maar tiperend van Israel se hantering daarvan, sal 'n beskrywing van die ballingskap verbind word aan die vroeëre paradigmatiese gebeure van die skepping, sondeval, uittog uit Egipte as die nuutste episode wat eweneens ' $n$ paradigmatiese gebeure is in die bestaan van Israel in sy historiese verbintenis aan God. Volgens Nineham: "It is when seen as a part of that sequence - as an episode in a super-historical story - that this genuinely historical event could become for the Jews 'elucidatory for all occasions' and paradigmatic; and it is only within the context of that story that it can be an object of religious response" (1976, p 133).

Hans Frei het verkies om die verhalende lektuur van die Ou Testament te beskryf as "history-like". Nineham en Barr maak gebruik van die woordspeling "story-history". Barr is van oortuiging "that the great narrative complex of the Bible is indeed a powerful indicator of the character of biblical faith, but that that narrative substance is better designated as 'story' than as "history"' (1980, $p$ vi). Soms kom die verhalende lektuur baie naby aan wat ons as geskiedenis kan bestempel. Soms beweeg dit verder weg en vertoon mitiese en legendariese elemente. Die verhaal moet dus steeds gehanteer word aan die hand van die literêre vorm daarvan, want 
eerder as die reëls van die geskiedenis en die tradisie, is dit die wetmatighede van die letterkunde waaraan die verhaal verbind is.

Ter opsomming blyk dit dus dat die verhalende lektuur in die $\mathrm{Ou}$ Testament as een kategorie onder baie beskou kan word, nie as geskiedenis in ons sin van die woord uitgelê kan word nie, maar aan die hand van sy literêre aard verstaan moet word volgens die eie idioom van die Bybel.

\section{HET DIE OU TESTAMENT 'N "MITTE", 'N MIDDELPUNT?}

Die laaste vraag is dié na 'n sentrale gedagte in die hele Ou Testament. Bestaan daar ' $n$ sentrale tema of een of ander deurlopende gedagte waarmee al die dele van die Ou Testament in verband gebring kan word en in die lig waarvan elke teks verstaan kan word? Die antwoord is eenvoudig: nee. Niemand kon nog tot op datum so 'n sleutel vind "in hierdie versameling van wyduiteenlopende godsdienstige, nasionale en wysheidstradisies van oor ' $n$ hele millennium, met sy talle parallelle dele en oorkruis-verbindings met en ontlenings aan godsdienstige en ander tradisies van buite die Bybel" (Gunneweg, 1978, p 85) nie. Pogings om die materiaal van die Ou Testament te sistematiseer aan die hand van 'n eksterne stelsel wat aan die dogmatiese teologie ontleen is, was telkens onsuksesvol. ' $n$ Teologie-antropologie-soteriologiese stelsel, soos Sellin, Köhler, Baab, Jacob en Van Imschoot gebruik het, kon nie daarin slaag om die essensie van die Ou Testament weer te gee nie. Die Ou-Testamentiese teologie moet as historiese wetenskap hom eerder by die literêre en historiese vorm van die $\mathrm{Ou}$ Testament bepaal, en die Dogmatiek moet van daardie resultate gebruik maak om in die taal van vandag te sê wat die kerk glo en bely. Hasel stel dit ook baie duidelik dat dit slegs "die benadering tot die Bybel is wat na 'n interne sleutel soek, na een wat uit die Bybelse materiaal self voortkom, wat voldoende en reg kan wees om die teologie of teologieë van die Bybel te beskryf" (1972, p 98). Die talle pogings wat daar geloods is om met ' $n$ enkele binne-Bybelse term die inhoud van die Ou Testament te omskryf, kon nie een 'n werklike term wat alles insluit vind nie. Eichrodt se verbondsbegrip, Vriezen se gemeenskapsidee, Köhler se heerskappy van God, Zimmerli se Naam van God, en so meer, selfs Von Rad se tradisiehistoriese benadering wat op die Deuteronomistiese teologie van die geskiedenis gebaseer is, en Fohrer se dubbele konsep van die heerskappy van God en gemeenskap tussen God en mens, kan nie al die materiaal van die $\mathrm{Ou}$ Testament akkommodeer nie. Hulle vorm 'n "alte smalle basis waarop 'n Ou-Testamentiese teologie gebou kan word, wat nie die wesenlike aspekte van die Ou-Testamentiese geloof na 'n minderwaardige en onbelangrike posisie verplaas nie" (Hasel, 1972, p 99). 
Claus Westermann probeer in sy teologie van 1978 om met die geheel van die Ou Testament te werk. Sy stelsel werk met die geheel kanon as 'n gebeure waarin die woorde wat van God kom, in voortdurende wisselwerking staan met die antwoord van die mense wat hierdie gebeure wedervaar. So probeer Westermann beide die sistematiese as die historiese aspek in sy stelsel te huisves. Die gebeure wat tussen God en mens afspeel, wissel vanaf die toneel van die volk, die enkeling, tot die hele mensdom. In Walter C Kaiser se "Toward an Old Testament Theology" (1979), vind ons ook die poging om sistematies sowel as diakronies te werk te gaan. Kaiser huldig die mening dat die Ou-Testamentiese kanon epigeneties gegroei het vanaf die eerste dele van die kanon tot by die laaste vorme. In die eerste deel van Genesis 1-11 was daar bepaalde kernpunte ("nodal points") waarby die volgende geslag skrywers aangesluit het. Hulle bring dan 'n versameling geskrifte tot stand in Genesis 12-50 wat by hierdie temas aansluit en dit in daaropvolgende situasies uitwerk. Die Ou Testament is dan iets soos ' $n$ ketting waarvan die skakels onderling verbind is. ' $n$ Konstante, wat met verskillend onderverwante terme in die verskillende tydperke beskryf word, word so deur die verskillende eras wat die kanon aandui, nagevors. Die probleem by beide Westermann en Kaiser is dat hulle komplekse sisteme nog steeds nie wegkom van 'n simplistiese benadering tot die pluralistiese vorm van die Ou Testament nie. By Westermann is dit uiteindelik die vormgeskiedkundige teorie van die Psalmliteratuur en by Kaiser 'n literêre teorie van kanonvorming, wat die sleutel is waarmee hulle alles wil ontsluit.

Die beste benadering om te volg, is dié wat by Hans-Joachim Kraus en by Gerhard Hasel voorkom. Albei verklaar dat die hele Bybelse kanon in gedagte gehou moet word by die hantering van 'n Skrifgedeelte. "Aangesien geen enkele tema, skema, of motief omvattend genoeg is om ruimte te gee aan die wye verskeidenheid van Ou-Testamentiese gesigspunte nie, moet ' $n$ mens nie ' $n$ bepaalde konsep, formule, basiese idee of so wil gebruik as die middelpunt van die Ou Testament waardeur die veelvoud en verskeidenheid van Ou-Testamentiese getuienis gesistematiseer kan word nie" (Hasel 1972, p 139). Wat wel aanvaar kan word, is dat al die verskillende getuienisse oor God handel. Elke getuienis moet afsonderlik volgens sy taal, literatuur en historiese agtergrond ondersoek word om te hoor wat dit oor God sê. Eers dan sal vanuit die teologiese resultaat van die ondersoek duidelik word watter ooreenstemming daar bestaan met aangrensende dele, of groter eenhede, of boekdele of kanonsegmente. Langs hierdie weg, van wat Kraus noem, "Stückweise erkennen", moet induktief gewerk word vanaf die eksegese van die kleinste eenhede totdat die volle konteks van die kanon in sy wye verskeidenheid van ooreenkoms en verskeidenheid betrek is. 
Die groot vraag wat telkens voorop moet staan, is: Wat word hier op eiesoortige wyse, in eie idioom en vanuit die eie tyd oor God gesê? God is "ciie dinamiese en verenigende middelpunte van die $\mathrm{Ou}$ Testament" (Hasel, 1972, p 100). Deur die verskillende fases van die Ou-Testamentiese teologie kanon het ons juis geleer dat daar baie meer te sê is oor hierdie God van Abraham, Isak en Jakob, en die geslagte van die aarde, hierdie God wat hom in Jesus Christus geopenbaar het, as waaraan simplistiese sisteme ooit reg kan laat geskied.

\section{Bronne}

Barr, J 1963. The interpretation of Scripture II Revelation through history in the Old Testament and in modern theology. Interpretation 17, p 193-205.

Barr, J 1966. Old and new in interpretation. A study of the two Testaments. London: SCM Press.

Barr, J 1980. The scope and authority of the Bible. Explorations in theology, 7. London: SCM Press.

Childs, BS 1978. Biblical theology in crisis. Philadelphia: Westminster Press.

Childs, BS 1979. Introduction to the Old Testament as Scripture. London: SCM Press.

Gilkey, LB 1961. Cosmology, ontology, and the travail of biblical language. Journal of Religion. 41, p 194-205.

Gunneweg, AHJ 1978. Understanding the Old Testament. London: SCM Press.

Hasel, G 1972. Old Testament theology: basic issues in the current debate. Grand Rapids, Michigan: Eerdmans.

Kaiser, WC jr. 1978. Toward an Old Testament theology. Grand Rapids, Michigan: Zondervan.

Kosak, H 1968. Wegweisung in das Alte Testament. Stuttgart: Calwer Verlag.

Kraus, H-J 1970. Die Biblische Theologie. Ihre Geshichte und Problematik. NeukirchenVluyn: Neukirchener Verlag.

Nineham, D 1976. The use and abuse of the Bible. A study of the Bible in an age of rapid cultural change. London: SPCK.

Stuhlmacher, $\mathrm{P}$ 1979. Historical criticism and theological interpretation of scripture Toward a hermeneutics of consent. London: SPCK.

Von Rad, G 1969. Theologie des Alten Testaments. Band I. München: Chr Kaiser Verlag.

Westermann, C 1978. Theologie des Alten Testaments in Grundzügen, Göttingen: Vandenhoeck \& Ruprecht. 